\title{
Business ethics: Should the punishment fit the crime?
}

\author{
Leyland F. Pitt* \\ Graduate School of Business, University of Cape Town, Private Bag. Rondebosch 7700, Republic of South Africa \\ Richard T. Watson
}

Department of Management, College of Business Administration, Brooks Hall 419. University of Georgia, Athens Georgia 30603

Deon Nel

School of Business, University of Pretoria, Pretoria 0001, Republic of South Africa

Received 27 August 1990; accepled 25 September 1990

\begin{abstract}
In this pape an empirical investigation is reported of the attitudes of purchasing managers to the degree of wrongness of a range of ethically problematical issues and what the corresponding punishment should be for these actions. The study found a significant difference between what purchasing managers believe is wrong and how willing they are to punish transgressors. It is suggested that the largest difference between a wrongful action and its punishment occurs when the action is clearly wrong, but the financial impact upon the employer is minor. The paper concludes by suggesting areas for future research that could explore why there is a difference between a crime and its associated punishment.
\end{abstract}

\begin{abstract}
In hierdie referaat word die resultate van in empiriese ondersoek na die houdings van aankoopsbestuurders ten opsigte van problematiese etiese aangeleenthede en die toepaslike strafmaatreëls daarvoor gegee. In die studie is bevind dat daar 'n betekenisvolle verskil is tussen wat aankoopsbestuurders as verkeerd beskou en hulle bereidwilligheid om cortreders te straf. Daar word tot die gevolgtrekking gekom dat die grootste verskil tussen 'n verkeerde daad en die toepaslike aksie voorkom wanneer die aksie baie duidelik verkeerd is, maar die gevolge darvan vir die werkgewer minimaal is. Voorstelle oor verdere navorsing wat ondersoek instel na die verband tussen misdaad en die toepaslike straf, word gemaak.
\end{abstract}

-To whom correspondence should be addressed.

\section{Introduction}

'My object all sublime, I shall achieve in tine. To make the punishment fit the crime, the punishment fit the crime.'

So sings The Lord High Executioner in Gilbert and Sullivan's beloved operelta, 'The Mikado'. However, when the crime is white collar or has to do with possible corruption in business, it seems as though the 'objects all' of managers are just a little myopic. It appears that in some instances managers do not really want the punishment to fit the crime.

Considerable attention has been given in recent times to a vast array of ethical issues in management and business. The subject has not only been researched by academics, it is now also taught at the undergraduate and graduate levels of many business school programs. A number of new texts have appeared in the area (e.g. De George, 1986; Bowie, 1982; Davis and Frederick, 1984; Velasquez, 1982), and management journals are also devoting more pages to scholarly articles on the topic. These advances have also been mirrored in the business community, with an increased adoption of stated ethics policies by companies and in the promulgation of ethical codes of conduct by the business-related professions.

In the literature, there has been considerable discourse focussed on descriptive studies of what the ethical beliefs of managers are and why they behave or fail to behave in certain ways. There have been general surveys of ethical behaviour (Chonko and Hunt, 1985; Ferrell and Weaver, 1978; Rickleffs, 1983; Zey-Ferrell,
Weaver and Ferrell, 1979), and some theoretical models have been developed for integrated frameworks which explain how managers make ethical decisions (Ferrell and Gresham, 1985; Laczniak, 1983). There have also been a number of broad considerations of the issues involved (Brenner and Molander, 1977; Cavanaugh and Moberg, 1981; Sturdivant and Cocanaugher, 1973), the first important one being that of Baumhart (1961). Other researchers have focussed on more narrow functional areas of organisational activities (Tybout and Zaltman, 1974; Varble, 1972; Dubinsky, Berkowitz and Rudelius, 1980). The field of purchasing has been a functional area of business which has also received attention (e.g. Cummings, 1979; Davis, Rudelius and Buchholz, 1979; Mayer, 1970).

The impression is gained that the literature has covered everything from who, is doing what, where, why, to whom, and when. Furthermore, researchers now seem closer to knowing what managers think about the behaviour, what their peers think about it and to what extent they indulge in it, what opportunities there are for it to occur, and what top management does or can do to encourage or discourage it. One of the few gaps in the literature, however, seems to be what to do about it in terms of appropriate action. As far as can be ascertained, no studies have considered managers' views of what should be done, or what the people concerned see as appropriate action to be taken.

A number of organisations, as already alluded to, have cpdes of conduct, or policies on ethics, or both. These documents outline what the corporation believes 
to be right and wrong, and what is expected of individual employees in this regard. Yet in many of the corporate policies one could examine, there is very little said about what the organisation will do should an employee trespass. Vague mention seems to be made of 'dismissal' in certain circumstances, but this retribution is not specifically outlined for specific transgressions. In a broader societal context there appear to be two extremes on a retributional spectrum. At one end there are the codes of ethics of some of the various professions within business (such as human resources management, marketing and purchasing), which threaten dishonorable expulsion from the body as a most dire consequence of infringement. Whether this is indeed an effective deterrent measure could be an area for fruitful further research. Quite conceivably, the transgressor could easily continue practising in that profession. This is not the case in the medical, legal, business and accounting professions, where an infringement of the code could effectively bar the perpetrator from practising for a period, or perhaps permanently. At the other end of the punitive spectrum there is the law, with statutory penalties for infringements. Somewhere in between, there seems to be reality. But what is it? The study presented here attempts to explore the reality of retribution for infringements of corporate ethical standards.

\section{Comuption in business - the vulnerable area of purchasing}

Purchasing is an area of business which has been particularly prone to issues concerning ethics (Davis and Rudelius, 1979; Dubinsky and Gwin, 1981). As that functional domain of business which exercises considerable influence in the selection of suppliers, granting of orders and often the delineation of specifications, the purchasing function and purchasing managers in most organisations are confronted daily by ethical issues. Purchasing managers may have a lot of power (Strauss, 1962), which they are expected to exercise to keep costs down. However, their very use of this faculty confronts them with ethical issues they cannot always answer. Frequently, the purchasing job demands flexibility, and when ethical guidelines are put in writing this flexibility may be sacrificed.

This study examines aspects of corruption in business from the point of view of purchasing managers. Its particular objectives were to establish a relationship between a 'degree of wrongness' of ethically problematic actions and what purchasing managers as an organisational group believed were appropriate actions regarding these actions should the organisation become aware of them.

\section{Methodology}

The sample

A combination of judgement and probability sampling was used to select the respondents for this research. The respondents were selected on a stratified random basis. A total of 500 questionnaires, with instruction on their

\section{Table 1 Scenarios}

1. Bribe: A purchasing manager is offered a considerable sum on condition that he awards a large contract to a certain company. He accepts the offer.

2. Hunting trip: A project engineer awards a sizable bid. A week later the company invites him on an all expensespaid shooting trip to their private wildlife reserve. He accepts their offer.

3. Lunch: Members of a company negotiating team eccept a potential supplier's invitation to lunch.

4. Competitor information: On condition that he let them know of rival bid prices, a bid official is offered the opportunity of having his home carpeted throughout. He supplies every price tendered.

5. Christmas gif: A company official receives a bottle of whisky from a supplier as a Christmas gift. He phones to say thanks.

6. Sporting event: Shortly after awarding a large contract, a company official and his son are invited to join the suppliers at their private box at a major football match. They accept the offer.

7. Large gifts: Shortly before the announcement of a large new bid, one of the bid officials has a side of beef and a case of whisky delivered to his home by one of the parties. He accepts the gifts.

8. Geologist knowledge: A geologist working for a major mining group gains important information regarding the development of a new reef. He immediately buys 1,000 company shares.

9. Free weekend: A branch manager receives a voucher for a weekend's stay at a holiday resort from a supplier, as a birthday present. His secretary telephones his thanks.

10. Fuel siphoning: A senior manager siphons fuel from his company car and transfers it to his wife's car for her shopping.

11. False expense claim. The marketing manager and his wife entertain friends at a top restaurant. He books the bill to his expense account ... 'dined with potential customers'.

12. Free overseas trip: A company is known to be in the market for twenty heavy vehicles. One of the potential suppliers invites the specification engineer on an overseas trip so that he can 'visit their highly sophisticated facilities'. He accepts the offer.

13. Insider trading: The financial manager knows that the next company report will be the best yet. He instructs his broker to purchase 10,000 shares on his behalf.

14. Free groceries: On returning from a visit to a supplier a buyer finds his car trunk filled with groceries. He does nothing about this.

15. Night out: On arrival at his hotel in another city, a company purchasing manager receives a phone call from the secretary of a supplier's sales manager. Her boss, she says, has instructed her to take him out for a 'night on the town'. He accepts her invitation.

completion, were mailed to the purchasing managers of 500 companies selected by means of strata criteria requiring employment exceeding 500, and (in order to eliminate service organisations) electrical power 
consumption exceeding 150,000 kilowatts per hour per month. A good response rate, for a mail survey, was achieved. Of the 500 managers approached, 146, or 29.2 per cent, responded.

\section{The study}

The empirical procedure expanded on the methodology used in a study by Pitt and Abratt (1986). A questionnaire designed to measure the atcitudes towards potentially corrupt business practices, presented in the form of scenarios, was set before respondents. While these scenarios do not all directly involve purchasing or purchasing managers, they do cover a range of issues which may be encountered in business. The scenarios used appear in Table 1. The issue to be considered in this study was whether there is a difference between purchasing managers perceptions of what is a crime (very wrong) and the corresponding punishment/ retribution for that crime/wrongdoing.

The questionnaire required respondents to indicate:

1. How wrong they felt each situation to be, on a fourpoint scale, where $1=$ definitely wrong, $2=$ wrong, 3 $=$ understandable, $4=$ not wrong at all.

2. The appropriate action which should be taken by management/the firm should they become aware of the situation, on a four-point scale, where $1=$ prosecute or take legal action, 2 = dismiss the guilty party, $3=$ give a warning, $4=$ do nothing.

\section{Results and discussion}

The response for each question was treated as approximating a continuous variable, an assumption that would be typically made in social science when analyzing ordered response categories such as the scenarios used in this study.

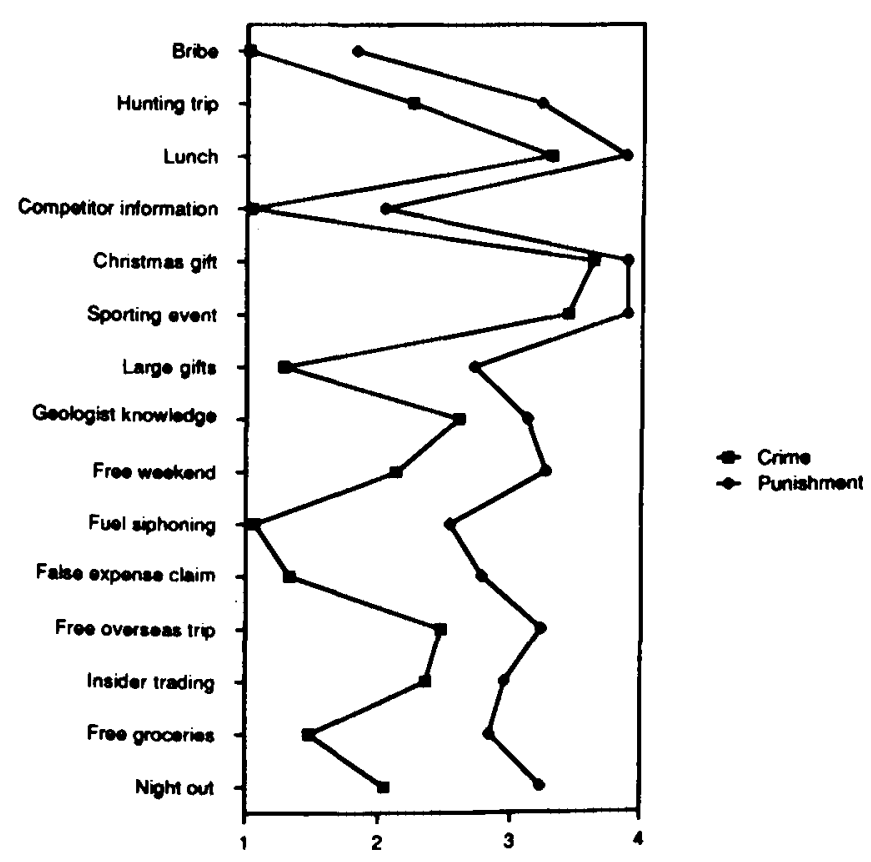

Figure 1 The need for a corporate ethics policy - mean responses for each scenario by crime and punishment
Mean responses, in graphical form, to the 15 scenarios for respondents attitudes toward an action and the corresponding severity of punishment are displayed in Figure 1. We conclude that there is a difference between purchasing managers' perceptions of what is a crime and the corresponding degree of punishment as graphically illustrated in Figure 1, purchasing managers seem reluctant to make the punishment fit the crime. For example, fuel siphoning, which is judged to be very wrong, should not attract a severe penalty in the opinion of purchasing managers. Canonical discriminant analysis using the SAS (1985) GLM procedure, which was used to explore the difference between attitudes towards 'crime' and 'punishment', indicates that $86 \%$ of the variation in responses can be explained by the 'crime' and 'punishment' dichotomy. The standardized canonical coefficients and mean responses, shown in Table 2, provide clues as to where there are gaps in difference between what purchasing managers consider to be a crime and what the punishment should be.

One would expect attitudes towards crime and punishment to vary with the offense. Thus, actions which are considered to be relatively innocent are likely to attract little or no punishment. Conversely, activities that are perceived to be grossly improper should be allocated a severe penalty. Those situations where there is a balance between the crime and the punishment are indicated by canonical correlation coefficients that are close to zero. For example, the sporting event $(-0.0874)$ is considered to be relatively innocent action that should attract minimal penalty, while taking a bribe $(0.1326)$ is considered definitely wrong and merits dismissal.

Table 2 Standardized canonical correlation coefficients and mean scores

\begin{tabular}{lccc}
\hline & $\begin{array}{c}\text { Standardized } \\
\text { canonical } \\
\text { coefficient }\end{array}$ & $\begin{array}{c}\text { Crime } \\
\text { mean }\end{array}$ & $\begin{array}{c}\text { Punishment } \\
\text { mean }\end{array}$ \\
Scenario & 0.1326 & 1.02 & 1.77 \\
\hline Bribe & -0.0109 & 2.12 & 3.16 \\
Hunting trip & -0.0409 & 2.95 & 3.75 \\
Lunch & -0.4081 & 1.02 & 1.95 \\
Cormpetitor information & -0.1620 & 3.58 & 3.95 \\
Christmas gift & -0.0874 & 3.36 & 3.85 \\
Sporting event & -0.4120 & 1.27 & 272 \\
Large gifts & -0.1723 & 2.54 & 298 \\
Geologist knowledge & 0.0439 & 1.93 & 3.25 \\
Free weekend & -0.6607 & 1.13 & 259 \\
Fuel siphoning & 0.4833 & 1.36 & 281 \\
False expense claim & 0.0110 & 2.28 & 3.14 \\
Free overseas trip & 0.0803 & 2.24 & 2.91 \\
Insider trading & 0.3474 & 1.38 & 2.86 \\
Free groceries & 0.1989 & 1.96 & 3.28 \\
\hline Night oun & & \\
\hline
\end{tabular}

Note: For the convenience of the reader, we show the respective standardized cenonical coefficient in two parentheses when a scenario is mentioned in the text of the paper. 
However, there are situations where purchasing managers do not think that the punishment should fit the crime. A high absolute value for the canonical correlation denotes a scenario where there is a discrepancy between the crime and the punishment. The most glaring example is fuel siphoning $(-0.6607)$, which is assessed as unforgivable, but attracts a level of retribution that is more fitting of a misdemeanor. Purchasing managers recognize that fuel siphoning is a criminal act, but do not believe that this transgression should be harshly penalized. Actions falling into the same category (demonstrably wrong, but not to be castigated) are: large gifts $(0.4120)$, competitor information $(-0.4081)$, false expense claims $(0.4833)$, and free groceries (0.3474).

Another perspective on the data is gained by plotting the mean responses for each of the scenarios as is depicted in Figure 2. This plot clearly demonstrates that in every case, the punishment is less severe than the crime. If a line is traced from the bottom right corner to the top left corner (shown as a dashed line in the diagram), we find that all observations are to the right of this diagonal line. This indicates that the mean response for the crime is consistently higher than the corresponding response for the punishment. We can isolate a 'critical' region of the figure which consists of serious wrong doings that, it is felt, should not be similarly punished. This is done by drawing a line parallel to the dashed diagonal line and two units to the right so that all observations in this area represent actions where there is a large discrepancy in the perception of the wrongfulness of the action and the matching punishment. The more trivial actions can be discarded by excluding all scenarios above a line through the 'wrong' tick point of the vertical axis.

We thus arrive at the shaded region in Figure 2. This intuitive approach produces similar results to an analysis of the canonical coefficients. Four scenarios have a clear mismatch between crime and punishment: large gifts, free groceries, false expense claim, and fuel siphoning. Competitor informaton, free weekend, and night out are on, or near, the boundary of this region. Given the somewhat arbitrary nature by which the critical region is defined, it seems reasonable to examine more closely competitor information, because it falls near the lower boundary based on 'unforgivable', and to discard free weekend and night out, because they are near the upper boundary based on 'wrong'. Thus, with these adjustments, the graphical analysis confirms the canonical correlation analysis.

\section{Implications and conclusions}

The most important finding of this research is that there is an inconsistency in what some managers see as wrong and what they are willing to punish. It is therefore useful to consider the five scenarios where this occurs in some more depth. Firstly, we will examine fuel siphoning and false expense claims. Important characteristics of both of these crimes are that the gain is small - though if continually repeated could grow in size - and the usual

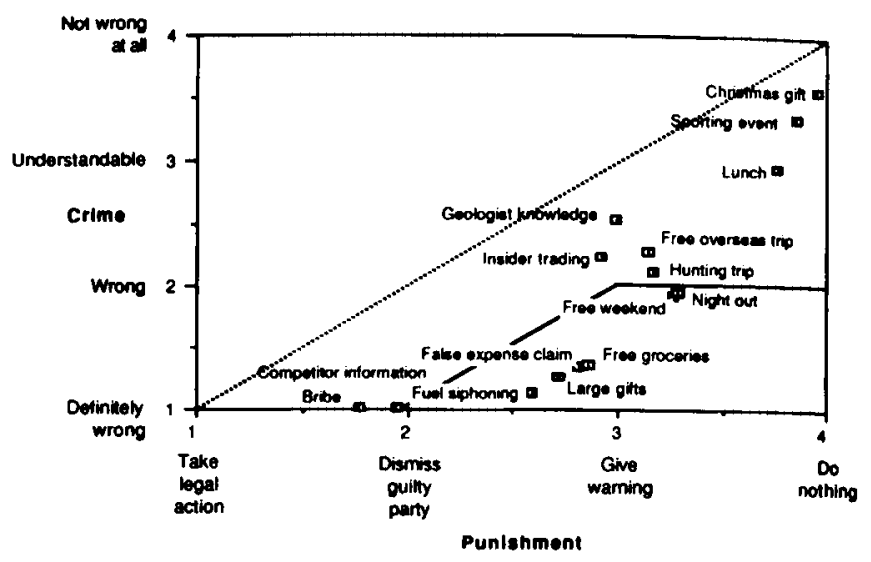

Figure 2 Crime by punishment - scatter plot of mean response for each scenario

punishment, dismissal, is rather costly to the employee. Inherently, there is a mismatch between the potential gain and the potential loss. Fuel siphoning and filing a false expense claim are, in most of the world's legal systems, thefts by a servant, acts which have traditionally been heavily punished by society.

The draconian laws dealing with servant theft are a product of an era when legislative assemblies were almost totally composed of men from the privileged upper class. These men had servants and, out of personal interest, passed legislation that was considered would be a deterrent to servants contemplating misappropriating household valuables. In this current age, servant theft may be viewed more lightly, especially by employees, the people who participated in this study, who are essentially servants of their company. Thus, while filing a false expense claim is recognized as wrong, purchasing managers appear to believe that the consequences of the crime are not particularly grave and are not willing to inflict a substantial penalty. It could even be the case that slight cheating on the expense account is the norm and that purchasing managers turn a blind eye to this transgression because it is part of the business culture. Petrol siphoning and false expense claims appear to be examples of 'acceptable' transgressions - crimes that we readily recognize, but are unwilling to punish.

Free groceries and large gifts are two actions that can also be considered jointly because of the common trait of the gain being unsolicited. The two scenarios strongly suggest that the recipient did not initiate the gift, but took the role of the willing receiver. Thus, while purchasing managers can recognize the impropriety of accepting large gifts, it could be suggested that they are unwilling to censure such action because the receiver was a passive actor in the exchange. It is difficult to explain why the overseas trip does not fall into the same region as free groceries and the large gifts, because it is also an unsolicited large free gift. There is obviously insufficient data and insight to suggest why this is so.

The competitor information scenario differs from the others in the critical region in that it represents a large gain for the employee, who has played an active role in the exchange by trading information for personal 
reward. While supplying competitor information and accepting a bribe are reckoned to be very wrong, they differ in the extent of the punishment. The possible cause of the difference is that in the case of the bribe scenario the employer could lose from the exchange as the contract is not necessarily awarded to the besi supplier. In the case of competitor information, however, the scenario does not suggest any potential loss for the employer. Thus, a possible rationale which purchasing managers apply when considering the competitor information case is 'we know it's very wrong, but it does no harm to the employer'.

In this research, an attempt has been made to uncover situations where purchasing managers report large gaps between what they regard as a serious wrongdoing and the associated level of punishment. These circumstances can be classified as:

small illegal gain actively sought that does little harm to the employer;

large gain not actively sought that does little harm to the employer; and

large illegal gain that does little harm to the employer.

We speculate that the common thread is the low level of damage inflicted upon the employer, and we suggest that future research in this area could more actively pursue this premise in a number of ways. Firstly a similar method could be used, but with scenarios that were designed to explore differences in the financial impact upon the employer and perhaps with more specific reference to the purchasing situation. For exampie, one scenario could be a bribe which resulted in the employer paying an additional $\$ 1$ million for a computer system and the response to this scenario could be compared with another bribe example where the financial impact was $\$ 5,000$. Secondly, panel techniques could be used to reveal purchasing managers' rationale for varying the degree of punishment for wrongful acts. Thirdly, there is a need to investigate what companies do when they discover someone is filing a false expense claim, siphoning petrol or has accepted a large gift. Do firms make any serious attempt to detect such crimes? Are these types of activities accepted practice in business culture and socially sanctioned? We are reminded by Butler (1912) that 'Morality is ... the current feeling of one's peers.' The current feeling of many purchasing managers seems to be that that their peers' serious misdeeds should be treated as peccadillos.

\section{References}

Baumhart, R.C. 1961. How ethical are businessmen? Harv. Bus. Rev., Vol. 39. July-August, 6-31.

Bowie, J. 1982. Business ethics. Englewood Cliffs, New Jersey: Prentice Hall.

Brenner, S.N. and Molander, E.A. 1977. Is the ethics of business changing? Harv. Bus. Rev., Vol. 55. January-
Febsuary, 57-71.

Butler, S. 1912. Quoted in The International Thesaurus of Quotations. England: Penguin, 1970.

Cavanaugh, G.F., Moberg, DJ., and Velasquez, M. 1981. The ethics of organizational politics. Academy of Manage. Rev., No. 3, 363-374.

Chonko, L.B. and Hunt, S.D. 1985. Ethics and marketing management: an empirical examination. J. Bus. Res., Vol. 13, August, 339-359.

Cummings, G.F. 1979. Are purchasing ethics being put to the test? Iron Age, No. 222, September 24, 21-24.

Davis, K. and Frederick, W.C. 1984. Business and society: management, public policy and ethics. 5th ed. New York, NY: McGraw-Hill.

Davis, K., Rudelius, W. and Buchholz, R.A. 1979. Ethical problems of purchasing managers. Harv. Bus. Rev., Vol. 57, March-April, 8, 12, 14.

De George, R.T. 1986. Business ethics. New York, NY: Macmillan.

Dubinsky, A.J. and Gwin. J.M. 1981. Business ethics: buyers and sellers, J. Pur. and Mat. Manage., Winter, 9-15.

Dubinsky, A.J. and Berkowitz, E.N. 1980. Ethical problems of field sales personnel. MSU Business Topics. Vol.28. Summer, 11-16.

Ferrell, O.C. and Gresham, L.G. 1985. A contingency framework for understanding ethical decision-making in marketing. J. Marketing, Vol.49, Summer, 87-96.

Ferrell, O.C. and Weaver, M. 1978. Ethical beliefs of marketing managers. J. Marketing, Vol. 42, July, 69-73.

Laczniak, G.R. 1983. A Framework for analyzing marketing ethics. J. Macromarketing, No.1, Spring, 49-57.

Mayer, R.R. 1970. Management's responsibility for purchasing ethics. J. Purchasing, No.4., 13-20.

Pitt L.F. and Abrath R. 1986. Comption in business - are management attitudes right? J. Bus. Ethics, Vol. 5, 39-44.

Rickleffs, R. 1983. On many ethical issues, executives apply stiffer standards than public. Wall Street Journal, Nov 1.

SAS Institute Inc. 1985. SAS user's guide: statistics, version S edition. Cary, NC: SAS.

Strauss, G. 1962. Tactics of lateral relationships: the purchasing agent. Administrative Science Quarterly. Vol. 7, September, 161-186.

Sturdivant, F.D. and Cocanaugher, A.B. 1973. What are ethical marketing practices? Harv. Bus. Rev., Vol.5l, November-December, 10-12, 176.

Tybout, A.M. and Zaltman, G. 1974. Ethics in marketing research: their practical relevance. J. Marketing Research, No. 11, November, 357-368.

Varble D.L. 1972. Social and environmental considerations in new product development. J. Marketing, No. 36, October, 11-15.

Velasquez, M. 1982. Business Ethics. Englewood Cliffs, NJ: Prentice Hall.

Zey-Ferrell, M., Weaver, M. and Ferrell, O.C. 1979. Predicting unethical behavior among marketing practitioners. Human Relations, Vol.7, 557-569. 